\title{
Can anti-osteoporotic therapy reduce adjacent fracture in magnetic resonance imaging-proven acute osteoporotic vertebral fractures?
}

Ying-Chou Chen ${ }^{1 *}$ and Wei-Che Lin $^{2}$

\begin{abstract}
Background: Adjacent fracture of the cemented vertebrae result from crushed fragile trabeculae during follow-up, suggesting impaired bone marrow integrity. This study aimed to determine if anti-osteoporotic therapy can decrease the risk of adjacent fracture in patients after vertebroplasty.

Methods: This retrospective study reviewed of cases of osteoporotic patients with magnetic resonance imaging (MRI)-proven acute vertebral fractures between 2001 and 2007. Osteoporotic patients were investigated as determined by pre-operative MRI with subsequent adjacent fracture of the cemented vertebrae and for the possibility of anti-osteoporotic therapy decreasing the progression of collapse after a minimum of 6 months follow-up. All associated co-morbidities were recorded, as well as the use of anti-osteoporotic drugs (i.e., bisphosphonate, raloxifen, calcitonin, and teriparatide). Cox regression analysis was also performed.

Results: The 192 vertebral fractured patients who underwent vertebroplasty and anti-osteoporotic therapy had a mean age of $74.40 \pm 6.41$. The basic characteristics of patients with and without adjacent fracture differed in age, body mass index, rheumatoid arthritis, and use of glucocorticoids and anti-osteoporotic drugs (Table 1). Using the Kaplan-Meier curve, anti-osteoporotic therapy after vertebroplasty had a significant effect on adjacent fracture ( $p=0.037$, by log rank text). After adjusting for potential confounders, patients with anti-osteoporotic therapy still had a lower adjacent fracture rate than patients without antiosteoporotic therapy ( $p=0.006$; HR: $2.137,95 \% \mathrm{Cl}: 1.1238-3.690)$. The adjacent fracture rate also increased in old age ( $p=0.019$; HR: 1.049; $95 \%$ Cl:1.008-1.039) and among smokers ( $p=0.026 ; \mathrm{HR}: 3.891 ; 95 \% \mathrm{Cl}$ : 1.175-12.890).
\end{abstract}

Conclusions: In this study, adjacent fracture of cemented vertebrae is inevitable after vertebroplasty but can be mitigated by anti-osteoporotic therapy to increase bone mass.

Keywords: Osteoporosis, Vertebral fracture, Adjacent fracture, Anti-osteoporotic therapy

\footnotetext{
* Correspondence: r820713@ms13.hinet.net

1Department of Rheumatology, Kaohsiung Chang Gung Memorial Hospital,

Chang Gung University College of Medicine, 123 Ta-Pei Road, Niao-Sung

District, Kaohsiung 833, Taiwan

Full list of author information is available at the end of the article
} 


\section{Background}

Spine fractures are common with aging. The risk of osteoporotic spine compression fracture is estimated to be $18 \%$ in women and $11 \%$ in men [1]. Symptomatic spine fractures increase mortality by up to $15 \%$ [2] and some become disabled by severe pain and lasts for $2-3$ months.

Acute vertebral fractures with persistent pain are frequently managed with vertebroplasty [3]. It had been widely used in recent decade. Although it had favorable clinical outcomes, few studies on mortality among patients with vertebroplasty were reported $[4,5]$. Despite its safe and efficient, there are still some risks, including the development of new adjacent fractures at the non-treated vertebrae [6].

Anti-osteoporotic therapy is reported to increase bone mineral density. Patients who received antiosteoporotic treatment reduced incidences of vertebral fractures [7]. If treating osteoporosis have benefit on adjacent fracture after vertebroplasty, it will had important implications in skeletal health care. So this study investigate whether osteoporosis treatment can affect adjacent fracture rates in patients after vertebroplasty procedure.

\section{Methods}

The retrospective study reviewed osteoporosis patients with acute vertebral fractures which were proven by magnetic resonance imaging (MRI) and defined as low signal intensity (SI) on $\mathrm{T} 1$ and enhanced SI at T2-weighted of the injured vertebral body [8]. All of the patients were treated with vertebroplasty were performed in all of the patients. Chang Gang Memorial Hospital's institutional review board reviewed and approved the study protocol, which was conducted in Good Clinical Practice Guidelines. In accordance with local government's law, no additional informed consent was required. All information was de-identified before data analysis.

Only those treated with for a single vertebral fracture were enrolled. Patients previously using anti-osteoporotic drugs were also been excluded. The medical records were reviewed and the new fractures were evaluated from the imaging follow-up.

Pre- and post-vertebroplasty radiographs and those taken more than 6 months after the procedure were obtained. Those without available radiographs were excluded from the study.

Standard methods was used to measure the height of the anterior border of the collapsed vertebral body [9]. The anterior vertebral height $(\mathrm{AVH})$ was measured Differences of AVH within $1 \mathrm{~mm}$ were considered unchanged [10] and to avoid biases from technical factors or inappropriate measurement.
All of the study patients were recorded with, age, sex, body mass index (BMI, $\mathrm{kg} / \mathrm{m}^{2}$ ), and all co-morbidities such as diabetes, hypertension, and liver and renal disease. The use of anti-osteoporotic drugs (i.e., alendronate, raloxifen, calcitonin, and teriparatide) were reviewed. The duration of osteoporotic therapy was followed by local government's policy with teriparatide (18 months), bisophosphonate and raloxifen, calcitonin (long term used).

\section{Statistical analysis}

Statistical analysis was performed using the SPSS software, version 21.0 (SPSS, Chicago, IL, USA). Patient characteristics were reported as simple descriptive statistics (i.e., mean \pm standard deviation [SD]). Different groups of anti-osteoporotic agents were compared using Kaplan-Meyer analysis with the log rank test. Independent $t$-test was compared for independent means, while relationships between categorical variables were evaluated by the Chi-square test. Cox regression test was used for potential confounders.

\section{Results}

Of 192 patients enrolled in this study, 86 (44.8\%) used alendroante, 38 (19.8\%) used raloxifen, $18(9.4 \%)$ used calcitonin, and 12 (6.3\%) used teriparatide. All were grade 3 by semi-quantitative grading for vertebral fracture and had a $\mathrm{T}$ score less than -2.5 by bone densitometry. Their mean age was $74.40 \pm 6.41$ years. 84 patients had adjacent fracture (Fig 1). The basic characteristic of patients with and without adjacent fracture differed in age, BMI, rheumatoid arthritis, and glucocorticoid and antiosteoporotic therapy use (Table 1).

By the Kaplan-Meier curve analysis, anti-osteoporotic treatment after vertebroplasty had a significant benefit on adjacent fracture ( $p=0.037$, by log rank test) (Fig. 2). After adjusting for confounding factors such as smoking, alcohol consumption, hypertension, diabetes, cardiovascular, pulmonary, and liver diseases, and glucocorticoid use, those with anti-osteoporotic treatment still had a lower adjacent fracture rate than those who did not receive anti-osteoporotic therapy $(p=$ 0.006; HR: 2.137; 95 \% CI: 1.1238-3.690). The adjacent fracture rate also increased in old age $(p=0.019$; HR: 1.049; 95 \% CI: $1.008-1.039)$ and among smokers $(p=$ 0.026; HR: 3.891; 95 \% CI:1.175-12.890) (Table 2).

Evaluating the relationship between anti-osteoporotic drug use and adjacent fracture, the use of alendronate was associated with a significant reduction in adjacent fracture $(p=0.011)$, while raloxifen, calcitoninc, and teriparatide did not decrease adjacent fracture rate (Table 3). 


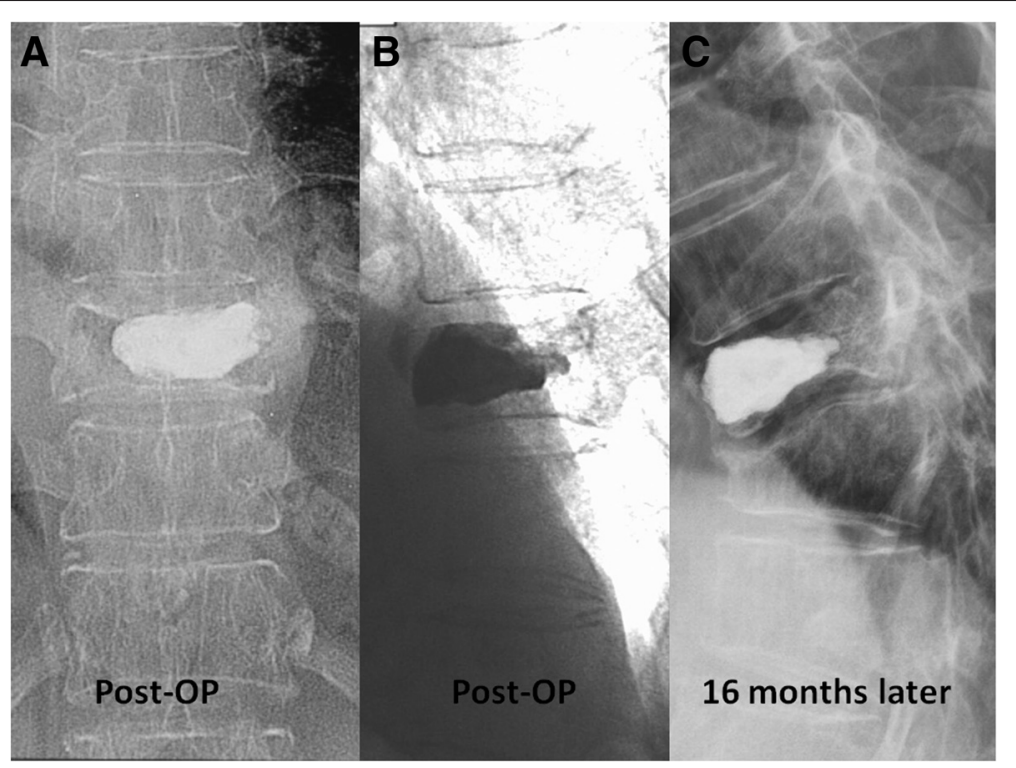

Fig. 1 A comparison of adjacent fracture for those with (blue line) and without (green line) anti-osteoporotic therapy, by Kaplan-Meier analysis

\section{Discussion}

Osteoporotic compression fractures increase the risk of new vertebral compression fracture even without percutaneous vertebroplasty [11]. Since vertebral compression fracture can lead to a collapse of adjacent vertebral bodies, it usually provokes a cascade of subsequent fractures.

Table 1 Characteristics of the study patients with and without adjacent fracture

\begin{tabular}{|c|c|c|c|}
\hline Variables & $\begin{array}{l}\text { Adjacent fracture } \\
(n=84)\end{array}$ & $\begin{array}{l}\text { No Adjacent fracture } \\
(n=108)\end{array}$ & $\begin{array}{l}p \\
\text { value }\end{array}$ \\
\hline Age (years) & $75.83 \pm 6.28$ & $73.28 \pm 6.31$ & 0.006 \\
\hline $\begin{array}{l}\text { Body mass index } \\
\left(\mathrm{kg} / \mathrm{m}^{2}\right)\end{array}$ & $21.68 \pm 4.11$ & $24.36 \pm 4.63$ & 0.001 \\
\hline Sex (\% Female) & 68 (81.0\%) & 98 (90.7 \%) & 0.057 \\
\hline $\begin{array}{l}\text { Spine fracture } \\
\text { (number) }\end{array}$ & $1.18 \pm 1.33$ & $1.89 \pm 1.87$ & 0.965 \\
\hline Smoking & $8(9.5)$ & $2(1.9)$ & 0.023 \\
\hline $\begin{array}{l}\text { Alcohol } \\
\text { consumption }\end{array}$ & $0(0)$ & $2(1.9)$ & 0.505 \\
\hline Rheumatoid arthritis & $10(11.9)$ & $2(1.9)$ & 0.006 \\
\hline Diabetes mellitus (\%) & $18(21.4)$ & $28(25.9)$ & 0.5 \\
\hline Hypertension & $44(52.4)$ & $48(44.4)$ & 0.309 \\
\hline \multicolumn{4}{|l|}{ Diseases } \\
\hline Cardiovascular & $0(0)$ & $2(1.9)$ & 0.505 \\
\hline Pulmonary & $6(7.1)$ & $2(1.9)$ & 0.141 \\
\hline Liver & $2(2.4)$ & $6(5.6)$ & 0.469 \\
\hline Glucorcorticoid use & $18(21.4)$ & $10(9.3)$ & 0.023 \\
\hline $\begin{array}{l}\text { Anti-osteoporotic } \\
\text { drugs use }\end{array}$ & $58(69)$ & $89(82.4)$ & 0.031 \\
\hline
\end{tabular}

Fracture of the adjacent vertebrae is a unique complication associated with vertebroplasty. The effects of vertebroplasty will increase strength of the stabilized vertebral bodies be greatest at vertebral levels near the treated vertebral body and augmented spinal segment have shown increased nucleus pulposus pressure, and lead to deformation of the adjacent endplate [12, 13], followed by decreasing segmental strength $[14,15]$. Some studies report that adjacent vertebral fracture occurs sooner than non-adjacent fractures [16], and majority of cases occurring within 30 days of surgery [17]. On the other hand, other studies refute these findings and find that adjacent untreated vertebral bodies do not undergo immediate changes after vertebroplasty and that intervention did not result in adjacent vertebral fractures [18, 19].

Adjacent vertebral fractures can be prevented by correctly recognizing and performing kyphoplasty in all fractured vertebrae identified by pre-operative MRI. Furthermore, the reported inevitable side effects of longterm analgesic medication in patients with chronic pain can be avoided $[20,21]$ through anesthesia and more radiation.

Anti-osteoporosis includes selective estrogen receptor modulators, bisphosphonates, and parathyroid hormone analogs. Among them, bisphosphonates are the compounds most commonly used drugs, which increase bone mass in osteoporotic patients $[3,8,15]$. In a study, alendronate group had less mean loss of vertebral height after 3 years of treatment than the placebo group [15].

In this study, anti-osteoporotic therapy significantly reduces adjacent fracture. Alendronate is the main drug 


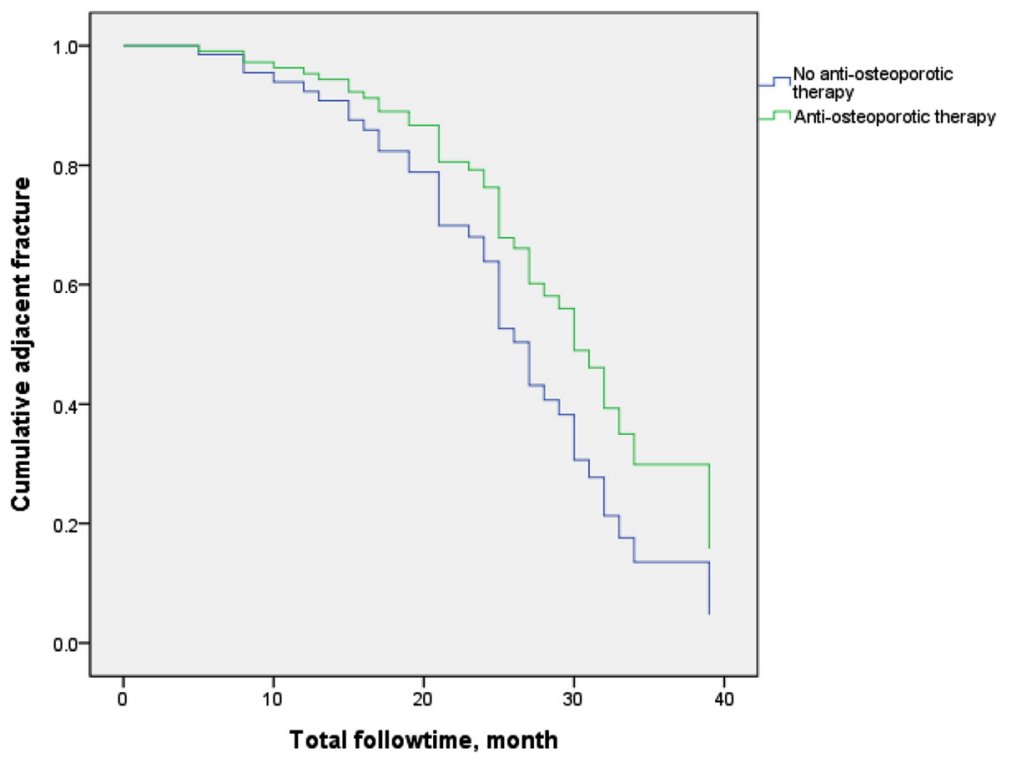

Fig. 2 Vertebroplasty was performed for 10th thoracic vertebra $(\mathbf{a}, \mathbf{b})$. c Patient developed a new adjacent compression fracture of 11th thoracic vertebra 16 months later

Table 2 Multivariable Cox regression analysis of the hazard ratios for adjacent fracture

\begin{tabular}{|c|c|c|c|c|c|}
\hline Variables & $\begin{array}{l}\text { Regression } \\
\text { coefficient }\end{array}$ & SE & Wald & $\begin{array}{l}p \\
\text { value }\end{array}$ & $\mathrm{HR}(95 \% \mathrm{Cl})$ \\
\hline Age & 0.048 & 0.021 & 5.471 & 0.019 & $\begin{array}{l}1.049 \\
(1.008-1.093)\end{array}$ \\
\hline $\begin{array}{l}\text { Body mass index } \\
(\mathrm{kg} / \mathrm{m} 2)\end{array}$ & -0.055 & 0.036 & 2.344 & 0.126 & $\begin{array}{l}0.946 \\
(0.882-1.016)\end{array}$ \\
\hline Sex & -0.595 & 0.515 & 1.335 & 0.248 & $\begin{array}{l}0.551 \\
(0.201-1.513)\end{array}$ \\
\hline Smoking & 1.359 & 0.611 & 4.943 & 0.026 & $\begin{array}{l}3.891 \\
(1.175-12.890)\end{array}$ \\
\hline $\begin{array}{l}\text { Alcohol } \\
\text { consumption }\end{array}$ & -13.295 & 383.923 & 0.001 & 0.972 & $0.00(0.000)$ \\
\hline $\begin{array}{l}\text { Rheumatoid } \\
\text { arthritis }\end{array}$ & 1.238 & 0.634 & 3.817 & 0.051 & $\begin{array}{l}3.448 \\
(0.996-11.938)\end{array}$ \\
\hline $\begin{array}{l}\text { Diabetes } \\
\text { mellitus }\end{array}$ & 0.262 & 0.300 & 0.762 & 0.383 & $\begin{array}{l}1.298 \\
(0.722-2.337)\end{array}$ \\
\hline Hypertension & -0.334 & 0.255 & 1.709 & 0.191 & $\begin{array}{l}0.716 \\
(0.434-1.181)\end{array}$ \\
\hline \multicolumn{6}{|l|}{ Diseases } \\
\hline Cardiovascular & -12.071 & 442.926 & 0.001 & 0.978 & $0.000(0.000)$ \\
\hline Pulmonary & -0.159 & 0.552 & 0.082 & 0.774 & $\begin{array}{l}0.853 \\
(0.289-2.519)\end{array}$ \\
\hline Liver & -0.175 & 0.735 & 0.057 & 0.811 & $\begin{array}{l}0.839 \\
(0.199-3.547)\end{array}$ \\
\hline $\begin{array}{l}\text { Glucocorticoid } \\
\text { use }\end{array}$ & -0.304 & 0.442 & 0.472 & 0.492 & $\begin{array}{l}0.737 \\
(0.310-1.756)\end{array}$ \\
\hline $\begin{array}{l}\text { Anti- } \\
\text { osteoporotic } \\
\text { therapy }\end{array}$ & 0.759 & 0.279 & 7.426 & 0.006 & $\begin{array}{l}2.137 \\
(1.238-3.690)\end{array}$ \\
\hline
\end{tabular}

Abbreviations: HR hazard ratio; SE standard error identified to improve adjacent fracture. Smoking and old age increases adjacent fracture so such patients warrant aggressive treatment.

This study has several limitations. First, the sample size is small. futhermore, because of the retrospective design, this study did not include datas, such as the use of calcium and vitamin D supplements. Nonetheless, in this cohort, as much data as possible was collected. Besides this study also included only fragility fractures in patients older than 50 years and exclude a secondary etiology such as cancer or pyogenic infection by MRI scans. Thus, the patients' fractures were due to osteoporosis.

\section{Conclusions}

Vertebroplasty can stabilize an fractured vertebra, but collapse of the cemented vertebrae can occur rapidly. In this study, we found adjacent fracture of a cemented vertebra is inevitable after vertebroplasty. Increase bone mass by anti-osteoporotic therapy after vertebroplasty may prevent the further collapse of the cemented vertebra.

Table 3 Drugs associated with decreasing risk of adjacent fracture

\begin{tabular}{ll}
\hline Drugs & $p$ value \\
\hline Raloxifen & 0.304 \\
calcitonin & 0.898 \\
Teriparatide & 0.878 \\
Fosamax & 0.011 \\
\hline
\end{tabular}




\section{Competing interest}

None of the authors have any conflicts of interest to declare.

\section{Authors' contributions}

YCC designed and performed the research; WCL and CCL performed vertebroplasty; WCC and FMS provided osteoporosis care; and YCC analyzed the data and wrote the final article.

\section{Acknowledgements}

The authors' thanks Kaohsiung Chang Gang Memorial Hospital to afford the clinical datas.

\section{Disclosure statement}

The authors have nothing to disclose.

\section{Author details}

'Department of Rheumatology, Kaohsiung Chang Gung Memorial Hospital, Chang Gung University College of Medicine, 123 Ta-Pei Road, Niao-Sung District, Kaohsiung 833, Taiwan. ${ }^{2}$ Department of Radiology, Kaohsiung Chang Gung Memorial Hospital, Chang Gung University College of Medicine, Kaohsiung 833, Taiwan.

Received: 1 November 2015 Accepted: 31 March 2016

Published online: 06 April 2016

\section{References}

1. Cooper C, Atkinson EJ, Jacobsen SJ, O'Fallon WM, Melton 3rd L. Population-based study of survival after osteoporotic fractures. Am J Epidemiol. 1993;137(9):1001-5.

2. Hasserius R, Karlsson MK, Jonsson B, Redlund-Johnell I, Johnell O. Long-term morbidity and mortality after a clinically diagnosed vertebral fracture in the elderly-a 12- and 22-year follow-up of 257 patients. Calcif Tissue Int 2005;76(4):235-42.

3. Garfin SR, Yuan HA, Reiley MA. New technologies in spine: kyphoplasty and vertebroplasty for the treatment of painful osteoporotic compression fractures. Spine (Phila Pa 1976). 2001;26(14):1511-5.

4. Lavelle WF, Khaleel MA, Cheney R, Demers E, Carl AL. Effect of kyphoplasty on survival after vertebral compression fractures. Spine J. 2008;8(5):763-9.

5. McDonald RJ, Achenbach SJ, Atkinson EJ, Gray LA, Cloft HJ, Melton 3rd LJ, et al. Mortality in the vertebroplasty population. AJNR Am J Neuroradiol. 2011:32(10):1818-23.

6. Lee WS, Sung KH, Jeong HT, Sung YS, Hyun YI, Choi JY, et al. Risk factors of developing new symptomatic vertebral compression fractures after percutaneous vertebroplasty in osteoporotic patients. Eur Spine J. 2006;15(12):1777-83.

7. Center JR, Bliuc D, Nguyen ND, Nguyen TV, Eisman JA. Osteoporosis medication and reduced mortality risk in elderly women and men. J Clin Endocrinol Metab. 2011:96(4):1006-14

8. Lin WC, Lu CH, Chen HL, Wang HC, Yu CY, Wu RW, et al. The impact of preoperative magnetic resonance images on outcome of cemented vertebrae. Eur Spine J. 2010;19(11):1899-906

9. Teng MM, Wei CJ, Wei LC, Luo CB, Lirng JF, Chang FC, et al. Kyphosis correction and height restoration effects of percutaneous vertebroplasty. AJNR Am J Neuroradiol. 2003;24(9):1893-900.

10. Hiwatashi A, Moritani T, Numaguchi Y, Westesson PL. Increase in vertebral body height after vertebroplasty. AJNR Am J Neuroradiol. 2003;24(2):185-9.

11. Heo DH, Chin DK, Yoon YS, Kuh SU. Recollapse of previous vertebral compression fracture after percutaneous vertebroplasty. Osteoporos Int. 2009:20(3):473-80

12. Baroud G, Nemes J, Heini P, Steffen T. Load shift of the intervertebral disc after a vertebroplasty: a finite-element study. Eur Spine J. 2003;12(4):421-6.

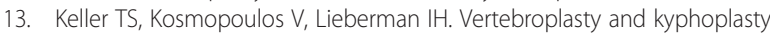
affect vertebral motion segment stiffness and stress distributions: a microstructural finite-element study. Spine (Phila Pa 1976). 2005;30(11):1258-65

14. Berlemann U, Ferguson SJ, Nolte LP, Heini PF. Adjacent vertebral failure after vertebroplasty. A biomechanical investigation. J Bone Joint Surg Br. 2002:84(5):748-52

15. Polikeit A, Nolte LP, Ferguson SJ. The effect of cement augmentation on the load transfer in an osteoporotic functional spinal unit: finite-element analysis. Spine (Phila Pa 1976). 2003;28(10):991-6.
16. Trout AT, Kallmes DF, Kaufmann TJ. New fractures after vertebroplasty: adjacent fractures occur significantly sooner. AJNR Am J Neuroradiol. 2006;27(1):217-23

17. Uppin AA, Hirsch JA, Centenera LV, Pfiefer BA, Pazianos AG, Choi IS. Occurrence of new vertebral body fracture after percutaneous vertebroplasty in patients with osteoporosis. Radiology. 2003;226(1):119-24.

18. Ananthakrishnan D, Berven S, Deviren V, Cheng K, Lotz JC, Xu Z, et al. The effect on anterior column loading due to different vertebral augmentation techniques. Clin Biomech (Bristol, Avon). 2005;20(1):25-31.

19. Kayanja MM, Evans K, Milks R, Lieberman IH. Adjacent level load transfer following vertebral augmentation in the cadaveric spine. Spine (Phila Pa 1976). 2006;31(21):E790-7.

20. Moulin DE, lezzi A, Amireh R, Sharpe WK, Boyd D, Merskey H. Randomised trial of oral morphine for chronic non-cancer pain. Lancet. 1996;347(8995):143-7.

21. Liegibel UM, Sommer U, Tomakidi P, Hilscher U, Van Den Heuvel L, Pirzer R, et al. Concerted action of androgens and mechanical strain shifts bone metabolism from high turnover into an osteoanabolic mode. J Exp Med. 2002:196(10):1387-92.

\section{Submit your next manuscript to BioMed Central and we will help you at every step:}

- We accept pre-submission inquiries

- Our selector tool helps you to find the most relevant journal

- We provide round the clock customer support

- Convenient online submission

- Thorough peer review

- Inclusion in PubMed and all major indexing services

- Maximum visibility for your research

Submit your manuscript at www.biomedcentral.com/submit
Biomed Central 